\title{
EVALUASI BENTUK DAN FUNGSI POHON PADA LANSKAP JALAN VETERAN KOTA MALANG, JAWA TIMUR
}

Oktaviana Hermince Bere, Rizki Alfian, Nuraini Nuraini

\begin{abstract}
Plants on the road landscape have various uses, both architectural, functional, ecological and aesthetic aspects. Functional means it can be used optimally and aesthetically and can be interpreted as something beautiful. In terms of aesthetics, trees can be enjoyed in terms of shape, color, aroma, texture, roots, stems, leaves, flowers and fruit that can provide spiritual satisfaction to humans. The purpose of this study is to identify and evaluate the shape and function of trees, using survey methods with quantitative parameters namely pollution reduction, noise reduction and physical barriers. The parameters are adjusted to the criteria for road landscape plant functions as determined by the Department of Public Works of the Directorate General of Highways (1996). The presence of plants on the Green Lane landscape of the Veterans Road has important significance in relation to security, safety and comfort of road users and the sustainability of the surrounding environment. Based on the results of the evaluation conducted, it can be concluded that the quantity and quality of plants on the site from the aspect of its function as a pollution reduction, noise reduction and room divider and aesthetic aspects have not fully met the criteria. Pollution reducing parameters, on the East side 73.8\%; Middle Park $86.46 \%$; and West 75.36\%, with good to very good levels. As a silencer, plants in the East 50.5\%; Middle Park 45.65\%; and West 61.65\%, with moderate to good levels. As a barrier, on the east side 66.00\%; Middle Park 64.2\%; and West 63.00\%, with good levels. As for aesthetics in crop selection, on the east side 22.89\%; Middle Park 25.35\%; and West 17.74\%, with poor ranking. Plant management on the East side is worth 76.8\%; Middle Park 87.36\%; and West 74.22\%, with good to very good levels.
\end{abstract}

Tanaman pada lanskap jalan memiliki berbagai kegunaan, baik aspek arsitektural, fungsional, ekologis dan estetika. Fungsional berarti dapat digunakan secara optimal dan estetis dan dapat diartikan sebagai sesuatu yang indah. Dilihat dari segi estetika, pohon dapat dinikmati dari bentuk, warna, aroma, tekstur, akar, batang, daun, bunga dan buah yang dapat memberikan kepuasan rohani kepada manusia. Tujuan penelitian adalah untuk mengidentifikasi dan mengevaluasi bentuk dan fungsi pohon, menggunakan metode survei dengan parameter kuantitatif yaitu pereduksi polusi, peredam kebisingan dan pembatas fisik. Parameter disesuaikan dengan kriteria fungsi tanaman lanskap jalan seperti yang di tetapkan oleh Departemen Pekerjaan Umum Direktorat Jenderal Bina Marga (1996). Keberadaan tanaman pada jalur hijau lanskap Jalan Veteran memiliki arti penting dalam hubungan dengan keamanan, keselamatan serta kenyamanan pengguna jalan dan keberlanjutan lingkungan di sekitarnya. Berdasarkan hasil evaluasi yang dilakukan, dapat disimpulkan bahwa kuantitas dan kualitas tanaman pada tapak dari aspek fungsinya sebagai pereduksi polusi, peredam kebisingan dan pembatas ruang dan aspek estetika belum sepenuhnya memenuhi kriteria. Parameter pereduksi polusi, pada sisi Timur 73,8\%; Tengah Taman 86,46\%; dan Barat 75,36\%, dengan tingkatan baik hingga sangat baik. Sebagai peredam kebisingan, tanaman di daerah Timur 50,5\%; Tengah Taman 45,65\%; dan Barat 61,65\%, dengan tingkatan sedang hingga baik. Sebagai Pembatas, pada sisi Timur 66,00\%; Tengah Taman 64,2 \%; dan Barat $63,00 \%$, dengan tingkatan baik. Sedangkan untuk estetika dalam pemilihan tanaman, pada sisi Timur 22,89\%; Tengah Taman 25,35\%; dan Barat 17,74\%, dengan ketingkatan buruk. Pengaturan tanaman pada sisi Timur bernilai 76,8\%; Tengah Taman 87,36\%; dan Barat 74,22\%, dengan tingkatan baik hingga sangat baik.

\section{Keywords}

Bentuk; Jalan; Lanskap; Pohon

\section{References}

Booth, N.K. 1983. Basic Elements of Landscape Architecture Design. Illinois: Waveland Press Inc.

Carpenter, P.L, T.D. Walker and F.O. Lanphear. 1975. Plant in The Landscape. San Fransisco: Freeman and Co.

Direktorat Jenderal Bina Marga. 2010. Pedoman Teknis Penanaman Pohon pada Sistem Jaringan Jalan. Jakarta: Departemen Pekerjaan Umum.

Direktorat Jenderal Bina Marga. 1996. Tata Cara Perencanaan Teknik Lanskap Jalan. Departemen Pekerjaan Umum. Jakarta.

Grey. G.W and F.J. Deneke. 1978. Urban Forestry. New York: John Wiley and Sons, Inc.

Hidayat.2010. Kajian fungsi ekologi jalur hijau jalan sebagai penyangga lingkungan pada tol jagorawi. manusia dan lingkungan, 17(2): 124-133.

Hakim, R. dan H. Utomo. 2003. Komponen Perancangan Arsitektur Lanskap. Jakarta: Bumi Aksara.

Pambudi.2014. Evaluasi kerusakan fisik pohon dalam upaya mitigasi pohon tumbang pada jalur hijau jalan di jakarta pusat [skripsi].Bogor (ID): Institut pertanian Bogor.

Simonds, J.O. and B.W. Starke. 2006. Landscape Architecture. New York: Mc Graw-Hill Book Company Inc. Soetrisno, H. 2001. Patologi Hutan. Bogor:

Widyanti. 2012. Evaluasi fungsi dan struktur pohon pada lanskap jalan kapten muslihat terminal laladon, bogor [skripsi]. Bogor: Fakultas Pertanian, Institut Pertanian Bogor.

widayat 2008. Evaluasi jalur hijau jalan sebagai penyangga lingkungan sekitarnya dan keselamatan pengguna jalan bebas hambatan jagorawi [skripsi].Bogor (ID): Institut pertanian Bogor 